А. В. Ткач

\title{
ПРИКМЕТНИКОВІ СЛОВОСПОЛУЧЕННЯ ТЕРМІНОЛОГІЧНОГО ХАРАКТЕРУ В СУЧАСНІЙ МОВІ МЕДИЦИНИ
}

Ткач А. В.Прикметникові словосполучення термінологічного характеру в сучасній мові медицини.

У науковому дослідженні йдеться про складні номінації - композити термінологічного характеру в сучасній мові медицини. Акцент зроблено на прикметникових термінах-словосполученнях: дається оцінка таким багатокомпонентним утворенням, розглядаються їхні специфічні семантикоструктурні ознаки, своєрідні умови й особливості функціонування.

Ключові слова: термін(и), термінологія, українська медична термінологія, багатокомпонентні утворення, прикметникові словосполучення, терміни-словосполучення.

Ткач А. В. Прилагательные словосочетания терминологического характера в современном языке медицины.

В научном исследовании говорится о сложных номинациях - композитах терминологического характера в современном языке медицины. Акцент сделан на прилагательных терминахсловосочетаниях: дается оценка таким многокомпонентным образованиям, рассматриваются их специфические семантико-структурные признаки, своеобразные условия и особенности функционирования.

Ключевые слова: термин(ы), терминология, украинская медицинская терминология, многокомпонентные образования, прилагательные словосочетания, термины-словосочетания.

Tkach A. V. Adjectival Word Combinations of Terminological Character in Terms of Modern Language of Medicine.

The scientific research considers the complex nomination - composites of terminological character in the modern language of medicine. The author analyzes the adjective terms and phrases. An assessment of such multi-formations and semantic and structural features and secularities of functioning are emphasized.

Key words: terms, terminology, Ukrainian medical terminology, component formation, adjective phrases, terms, phrases.

Суттєвою рисою української терміносистеми 3 позицій сучасного словотвору є іiі неоднорідний характер. Так, усі термінологічні одиниці позділяють на дві групи (за формальною, структурною ознакою): 
1) одновербальні терміни (однослівні або гіпероніми); 2) полівербальні терміни (багатослівні) [3, с. 427]. Окремі мовознавці переконують, що понад $70 \%$ термінів у різних терміносистемах - це словосполучення [7, с. 171], саме вони становлять основний масив термінофонду [3, с. 427]. Не $\epsilon$ винятком і сучасна українська медична термінологія. Хоча базовий термінофонд іiі становлять однослівні (одновербальні) терміни, проте чимало медичної лексики сформовано двокомпонентними (полівербальними) термінами, периферійна зона доповнюється відповідно трьох-, чотирьох-, п'яти-, шестикомпонентними одиницями. Такі багатокомпонентні утворення є результатом опосередкованої вторинної номінації, оскільки термін змінює свою денотативно-сигніфікативну віднесеність, відзначається вмотивованістю, реалізуючи своє нове значення 3 натяком на сигніфікат конкретизуючого слова. Характер зазначених понятійно-наукових сполук визначається єдністю протилежностей таких базових одиниць, як семантична цілісність i структурно зумовлена самостійність кожного елемента, що $є$ засобом єдиної, але розщепленої наукової назви.

Унаслідок опосередкованої вторинної номінації з'являється термінсловосполучення. Щоправда, у сучасному термінознавстві таке поняття лінгвісти кваліфікують по-різному, зокрема: складений термін (Д. Лотте), складні слова (О. Кардащук, О. Кульбабська), багатокомпонентний термін (В. Чумак, С. Овсейчик), терміни-композити (Л. Азарова), аналітичні номінації (О. Чуєшкова) тощо. Проте найчастіше складні номінації термінологи називають термінами-словосполученнями (В. Даниленко, Т. Панько, І. Кочан, Г. Мацюк, А. Крижанівська, Л. Симоненко, А. Д'яков, Т. Кияк, 3. Куделько, Л. Вакарюк, С. Панцьо й ін.).

Українська медична терміносистема нині репрезентує чималу кількість термінів-словосполучень. Базовою одиницею (стрижневим словом) кожної словосполучної моделі $є$ термін-іменник, до якого на основі підрядного зв'язку приєднуються залежні компоненти (конкретизатори). Навколо опорної назви (ядерного субстантива) у медичних термінах групуються здебільшого прикметники, які формують 3 іменником стійкі форми номінацій, що характеризуються системністю, наявністю дефініції, стислістю та семантичною єдністю, відсутністю експресії та стилістичною нейтральністю: алергічна реакиія, коронарна недостатність, кровоносна система, високопатогенний вірус, донорська кров, органічна речовина, штучне запліднення й ін. Напр.: Протягом десятиріч продовжувалися дослідження, внаслідок яких з'явилися нові факти й розкрилися нові закономірності фізіологічних функцій органів внутрішньої секреції (Із підр.); Сурогатне материнство - це одна $з$ репродуктивних технологій, за допомогою якої здорова жінка на основі угоди (договору) після штучного запліднення виношує $і$ народжує дитину для іншої сім'ї (Із телепередачі); Як джерело вітаміну $B$, малина помічна 
при тривалому вживанні сульфамідних препаратів та антибіотиків вони знижують вироблення цъього вітаміну кишковими бактеріями (Із газети). Тут прикметники вказують на ознаки, різнопланово характеризуючи явище чи поняття. Здебільшого в наукових словосполуках вони передують іменниковим формам. Незалежно від лексикограматичного категорійного складу та словесної довжини такі термінисловосполучення виражають функціонально одне термінологічне поняття.

Досліджений матеріал переконливо засвідчує, що в медичній термінології найчисленнішими 3-поміж складених термінів $\epsilon$ моделі двокомпонентних словосполучень, утворених на базі субстантивносубстантивного та субстантивно-ад’єктивного зв'язків.

Субстантивно-субстантивні медичні терміносполуки формуються за схемою: [іменник (Н. в.) + іменник (Р. в.)]: відшарування сітківки, ерозія емалі, запалення нирки, корінь зуба, метод Павлова, намисто Венери тощо. Напр.: Салат - джерело зміцнення імунітету, добрий помічник у захисті організму від різних інфекиійних збудників та від такого важкого захворювання, як рак (Із газети); Суниці добре регулюють діяльність кимечнику цे обмін речовин, беруть участь у виведенні «поганого» холестерину і токсинів, справляють заспокійливу, сечогінну, глистогінну діi (І. Носаль).

Більшу групу складають субстантивно-ад'єктивні утворення, виражені іменником у Н. в. та узгодженого 3 ним відносного прикметника (рідше - дієприкметника): жовчний міхур, бронхіальна астма, вузький таз. Конкретизатори (доповнювальні компоненти) можуть бути і простими, i складними прикметниками: ендокринна система, шлункова рідина, кииково-илунковий тракт, иишкоподібна залоза та ін.

Зазначені терміни-словосполучення мають гнучку будову, унаслідок чого внутрішньоструктурна зміна номінативної одиниці, що стосується лише ii дистрибутивних характеристик, не заторкує семантичної тотожності. Таку видозміну варто визначити як власне структурну (формальну), у результаті чого маємо терміни 3 іншим порядком розташування його складових, порівн.: молочна катаракта - катаракта молочна, очне яблуко - яблуко очне, кісткова тканина - тканина кісткова. Напр.: Іноді нанізм (карликовість) розвивається у дітей внаслідок недоїдання, тяжких хронічних хвороб - ниркової недостатності, ревматизму, вад серия (Із підр.); Істотно поліпшує перебіг хвороби Бехтерева лікувальна фізкультура, спрямована на збереження рухливості й змічнення м'язів хребта. Ефективними бувають сегментарний $i$ загальний масаж, апаратна фізіотерапія (Із газети): $\rightarrow$ модель [прикметник + іменник]; Пилок көітковий - цінний оздоровчий засіб системної та метаболічної дій, який може бути рекомендований для оптимізації комплексного лікування хворих на хронічний пієлонефрит (Iз наук. зб.): $\rightarrow$ [іменник + прикметник]. Між такими структурно- 
співвідносними варіантами простежується певне стилістичне розрізнення: препозиція означення відповідає прямому порядку слів, а його постпозиція - інверсійному [3, с. 428].

Окрім того, серед медичних складених термінів, компоненти яких об'єднані підрядним зв'язком, більшість становлять двоскладові конструкції, які можуть бути презентовані й термінологічними одиницями (обидва слова), й лексемами, де означуване слово загальновживаного типу чи не термінологічного характеру: мозкова травма, флюорографічний метод, катаральний ларингіт, грудна жаба, очне дно, протока навкололімфатична, тазовий пояс, сонна артерія.

Крім двослівних термінів, прикметники входять до складу багатослівних виразів, що передають цілісні поняття: імемічна хвороба серия, хронічний гнійний гайморит, дисбактеріоз товстої кишки, гострий гематогенний остеомієліт трубчастих кісток. Зазвичай такі складені термінологічні структури утворюються за різними словотвірними схемами, найбільш поширеними $є$ трикомпонентні: прикметник + іменник + іменник (велике коло кровообігу, вроджена вада серия), прикметник + прикметник + іменник (багатофракційне дуоденальне зондування, хронічний обструктивний бронхіт), іменник + прикметник + іменник (вуздечка верхньої губи, шлуночок лівого передсердя) тощо. Напр.: Лікування гострої фази гаймориту передбачене в умовах стачіонару (Із підр.); Основними клінічними проявами імемічної хвороби є часті напади болю за грудниною (Із посібника); У хворих на тонзиліт завжди буває запалення піднебінних мигдаликів (Із підр.); 3 вірогідних оксидантних чинників $i$ посередників найбільше значення мають сигаретний дим, інфекції дихальних иляхів, запалення бронхіального дерева (Із наук. зб.).

Як бачимо, наведені трикомпонентні наукові назви виникають на базі одно- та двокомпонентних і утворюються аналогічно до складних слів через поширення двоскладних термінів новим визначальним формантом. Кожна перша морфема трикомпонентного складеного медичного терміна здебільшого $\epsilon$ видовою щодо відповідного двоморфемного слова [2, с. 30-33]. Тобто в зазначених термінах є структурно організуючий центр та визначальна (доповнювальна) група.

Отже, формування термінів-композитів відбувається на основі вже наявних лексичних одиниць, а їх виникнення «пояснюється необхідністю подальшої деталізації предметів, явищ, виражених однокомпонентними термінами, вони сприяють удосконаленню структури процесу інформації та комунікації» [2, с. 33].

Чотири-, п'яти-, шестикомпонентні терміни є менш численними в українській медичні термінології. Вони являють собою поєднання різноманітних компонентів за різними словотвірними моделями: запалення слизової оболонки рота, окістя краю зорового каналу, внутрішньоочна ділянка верхньої очної щүілини й ін. Напр.: Верхній косий м'яз ока 
починається від спільного сухожилкового кільия медіально від м'яза, щзо піднімає верхню повіку, і між верхнім та присереднім прямими м'язами очного яблука прямує допереду $і$ досередини (Із наук. зб.).

Низький рівень функціонування таких багатоскладових термінів зі значною інформативною насиченістю пояснюється громіздкістю, що наближає-таки їх до власне синтаксичних конструкцій. Тому досить часто вони замінюються (коли це можливо) або іншомовними термінами, або професіоналізмами. Напр.: Гемоглобін - ие складний білок, який входить до еритрочитів (червоних кров'яних клітин крові) ц̆ відповідає за доставку кисню до наших органів $i$ тканин (ІІ газети); Перфузія (пропускання крові крізв порожннину серця - штучний кровообіг) тривала понад дві години (Із газети); Епікард - зовнішній шир стінки серця (Із підр.); Перевантаження й потрясіння, щзо випали людству в двадиятому столітті, породили рак - переродження клітини, природу якого встановити поки щзо не вдається (О. Сизоненко); Нейролептик лікарська речовина, щио пригнічує деякі функції нервової системи й таким чином усуває тривогу, напруження $i m$. ін. (Великий тлумачний словник сум); Дисгідротична екзема характеризується утворенням мікровезикул (пухирців з водою) на бокових поверхнях пальців, рідше - на долонях і підошвах (Із газети); Вагус - блукаючий нерв. Гальмує функиію багатьох внутрішніх органів (М. Амосов).

За ступенем смислової роздільності складені терміни-композити умовно поділяють на: 1) стійкі багатокомпонентні медичні терміни, в яких підкреслюються тільки окремі зовнішні (рідше - внутрішні) ознаки предметів чи понять: барабанна перетинка, вушна раковина, жовта лихоманка, сонячне сплетіння та ін.; 2) терміни-словосполучення, для яких характерна формальна (умовна) роздільність компонентів: дихальні иляхи, сечостатева система, илункова кровотеча, серцевий ритм, слизова оболонка й ін.

Медичні терміни-словосполучення, як і складні терміни, виражають цілісне поняття, володіють багатством семантичної та стилістичної сполучуваності компонентів, $\epsilon$ «знаком-повідомленням і номінативним знаком» в одній словотвірній моделі. Вони громіздкі, менш економні, проте таке багатослів'я 3 необхідною чіткістю виражає певну наукову одиницю не тільки в граматичному, але й семантичному плані.

Отже, утворення нових термінів у медицині через словоскладання та основоскладання набуває все більшої впорядкованості й актуальності. Таке термінологічне словотворення - процес осмислений, що дозволяє контролювати й регулювати його. Це приводить до значного кількісного зростання продуктивних $\mathrm{i}$ поширених терміноелементів (власне українських і запозичених), урізноманітнює термінофонд мови медицини, дає змогу вибору щодо менш численних і непродуктивних словотворчих моделей та активно функціональних, краще пристосованих до законів української мови. 


\section{Література}

1. Азарова Л. С. Складні слова в українській мові: структура, семантика, концепція «золотої» пропорції / Л. С. Азарова. - Вінниця, 2000. - 222 с.

2. Безбородько Н. І. Композити в медичній термінології / Н. І. Безбородько // Мовознавство. - 1979. - № 3. - С. 30-33.

3. Вакарюк Л. Словосполучення термінологічного характеру в словотворі / Л. Вакарюк, С. Панцьо // Науковий вісник Чернівецького університету / наук. ред. Б. І. Бунчук. - Чернівці : Рута, 2007. Вип. 321-322. Слов'янська філологія. - С. 427-431.

4. Кардащук О. В., Кульбабська О. В. Синтаксична сутність мотивованості складного слова / О. В. Кардащук, О. В. Кульбабська // Актуальні проблеми менталінгвістики: зб. наук. статей за матеріалами V Міжнар. наук. конф. / наук. ред. Л. В. Корновенко. - Черкаси, 2007. - С. 66-68.

5. Карпіловська Є. А. Конструювання складних словотворчих одиниць / Є. А. Карпіловська. - К.: Наук. думка, 1990. - 156 с.

6. Осипенко 3. М. Моделі складних слів у сучасній термінології / 3. М. Осипенко // Українська мова і література в школі. - 1978. - № 11. - С. 82-84.

7. Панько Т. І., Кочан I. М., Мацюк Г. П. Українське термінознавство : [підручник] / Т. І. Панько, I. М. Кочан, Г. П. Мацюк. - Львів: Світ, 1994. - 216 с.

8. Ткач А. В. Особливості термінів-композитів у медичній термінології / А. В. Ткач // Науковий вісник Чернівецького університету / наук. ред. Б. І. Бунчук. - Чернівці : Рута, 2001. - Вип. 116. Слов’янська філологія. C. $88-92$. 